\title{
A Rarely Seen Symptomatic Intrapulmonary Bronchogenic Cyst
}

\author{
Nadir Görülen Semptomatik Intrapulmoner Bronkojenik Kist \\ Cenk Balta', Şamil Günay²
}

\begin{abstract}
A bronchogenic cyst (BC) is a rarely seen benign congenital malformation of the bronchial tree. These cysts are lined with secretory respiratory epithelium, and are similar to a normal bronchial tree, including cartilage, elastic tissues, mucous glands and smooth muscle. They are usually asymptomatic, but a cough, fever, and hemoptysis may be seen. On plain radiographies, cysts are homogenous lesions, but if there is additional infection, an air-fluid level can be seen. This is a description of a rarely seen symptomatic intrapulmonary bronchogenic cyst and a review of the published literature.
\end{abstract}

Key words: Bronchogenic cyst, intrapulmonary, Congenital malformation.

\section{Özet}

Bronkojenik kistler embriyonal dönemde trakeobronşial ağacın anormal gelişimine bağlı olarak oluşan, nadir görülen benign, kistik oluşumlardır. Normal bronşiyal sistem gibi mukus salgısı yapan hücreler, kıkırdak, elastik doku ve düz kaslar içerir. Çoğunlukla asemptomatik olmakla birlikte nadiren öksürük, ateş ve hemoptizi izlenebilir. Radyolojik olarak homojen kitle ve enfektif olduğunda hava-sıvı seviyesi içeren kistik kitleler olarak karşımıza çıkar. Bu yazıda nadir görülen intrapulmoner semptomatik bronkojenik kist olgusu literatür eşliğinde sunulmuştur.

Anahtar Sözcükler: Bronkojenik kist, intrapulmoner, konjenital malformasyon.
Bronchogenic cysts (BCs) are a rarely seen benign malformation of the trachea-bronchial tree that arise during the development of the embryonic foregut. They are lined with respiratory epithelium with a secretory function and are similar to a normal bronchial tree, including cartilage, elastic tissues, mucous glands and smooth muscle. It is usually located in the mediastinum and pulmonary parenchyma (1). Although it is asymptomatic in itself, a BC may be the reason for clinical presentations including cough, fever, and hemoptysis $(2,3)$. Radiologically, BCs are homogenous solid mass lesions and an air-fluid level may be visible in cystic mass lesions.

Presently described is a case of a rarely detected symptomatic intrapulmonary $B C$ and a review of the literature.
'Department of Thoracic Surgery, Şanlıurfa Training and Research Hospital, Şanlıurfa, Turkey

2Department of Thoracic Surgery, Harran University Training and Research Hospital, Şanlıurfa, Turkey
'Şanlıurfa Eğitim ve Araştırma Hastanesi, Göğüs Cerrahisi, Şanlıurfa

${ }^{2}$ Harran Üniversitesi Araştırma ve Uygulama Hastanesi, Göğüs Cerrahisi, Şanlıurfa

Submitted (Başvuru tarihi): 05.03.2018 Accepted (Kabul tarihi): 02.11.2018

Correspondence (iletişim): Cenk Balta, Department of Thoracic Surgery, Şanlıurfa Training and Research Hospital, Şanlıurfa, Turkey

e-mail: drcenkbalta@gmail.com 


\section{CASE}

A 35-year-old male patient presented with a cough and brown sputum. The results of a physical examination and laboratory tests were normal and unremarkable. A rightsided 3-cm mass with air-fluid levels was detected on a chest X-ray. A pulmonary abscess and a ruptured hydatid cyst were considered in the differential diagnosis. A thorax computerized tomography (CT) showed a focal bronchial dilatation and a soft tissue density inside the bronchus in the anterior segment of the right upper lobe that was $30 \times 22 \mathrm{~mm}$ in diameter (Figure 1). Broad spectrum antibiotic treatment was ad-ministered for 20 days. The same symptoms recurred after 4 months. As the patient was radiologically stable, a serratus muscle-sparing posterolateral thoracotomy was performed. The cystic lesion could not be visualized during peroperative exploration because of the intraparenchymal localization; however, using a syringe and radiological coordinates, we detected the intraparenchymal cystic lesion. A pneumotomy was performed using bipolar electrocautery and the mucous content was aspirated. The association between the cyst and the bronchial system can be seen in Figure 2. Resection of the cystic membrane and capitonnage were performed. The final pathology result was consistent with an infected intrapulmonary bronchogenic cyst.

\section{DISCUSSION}

BCs are usually located in the mediastinum and represent $18 \%$ of all mediastinum lesions (3). Intra-parenchymal BCs are less common and make up some $15 \%$ to $20 \%$ of all BCs. Neck, abdominal, supraclavicular, and intradiaphragmatic localizations are exceedingly rare (4-6). Symptoms such as a cough, dyspnea, and chest pain are often seen when the cyst is infected. Although intrapulmonary $\mathrm{BCs}$ are rare, they have a high risk of infection and are therefore more symptomatic than BCs of the

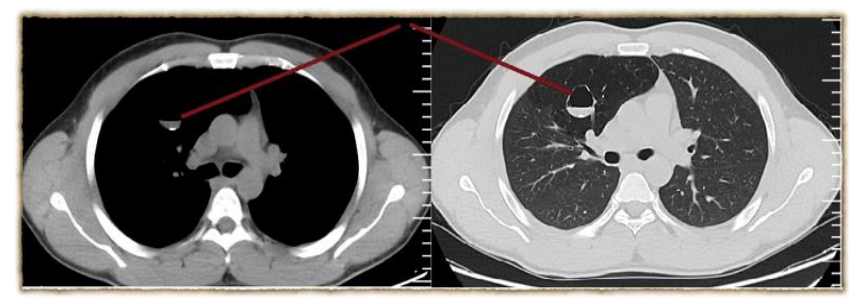

Figure 1: Thorax CT scan mediastinum. Hemoptysis and acute respiratory distress syndrome (ARDS) may occur as life-threatening symptoms (7). Tiwari et al. (8) indicated that two-third of BCs are symptomless while one-third has symptoms, and that the symptoms are related to the size and location of the cyst. Marshall et al. (9) determined that atrial fibrillation, pulmonary vein thrombosis, vena cava superior syndrome, and pleural effusion may be related to BCs. A cough and sputum were the primary symptoms in our case.

Radiologically, a BC is seen as a homogenous solid mass with a fluid density on a chest X-ray or CT scan. Due to the association with the bronchial system, intrapulmonary BCs may present as irregular masses (10). When the cyst is infected, it may resemble hydatid disease, pulmonary abscess, or a malignancy (11). The CT scans in our case suggested a ruptured hydatid cyst because of the air-fluid levels.

Some authors have suggested conservative treatment for BCs (12). But according to the risk of late complications, surgical risk, and malignant transformation, some authors have recommended surgery for asymptomatic cysts (8). Percutaneous catheter drainage and sterile alcohol ablation have been performed in selected cases, but remnants of the cystic membrane can flare up or create persistent symptoms (2). In our case, the cyst was symptomatic but small, and after conservative therapy and 4 months of follow-up, we decided to operate when the symptoms recurred.

In conclusion, a BC is a rare and commonly asymptomatic embryogenic abnormality that is often diagnosed coincidentally in adults. If homogenous, round masses in the pulmonary parenchyma and mediastinum are detected on a radiology examination, $B C$ should be kept in mind as part of the differential diagnosis.

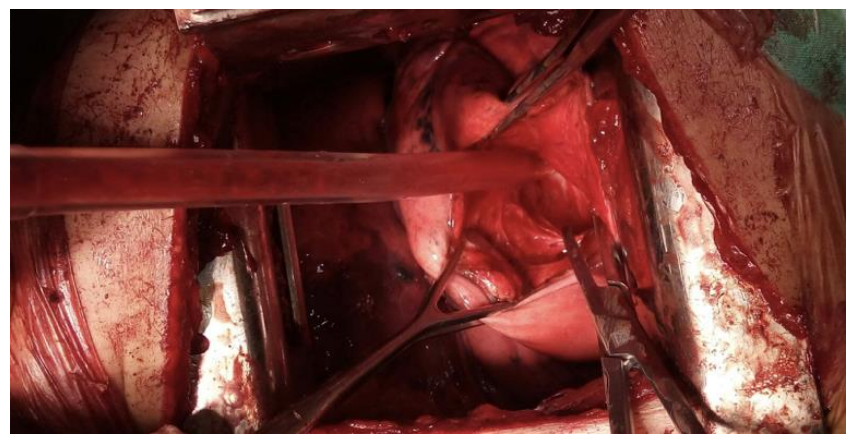

Figure 2: The Peroperative view 


\section{CONFLICTS OF INTEREST}

None declared.

\section{AUTHOR CONTRIBUTIONS}

Concept - C.B., S..G.; Planning and Design - C.B., S..G.; Supervision - C.B., Ş.G.; Funding - Ş.G.; Materials - C.B., S.G.; Data Collection and/or Processing - C.B., S.G.; Analysis and/or Interpretation - G.G.; Literature Review C.B.; Writing - C.B., S.G.; Critical Review - C.B.

\section{YAZAR KATKILARI}

Fikir - C.B., S..G.; Tasarım ve Dizayn - C.B., Ş.G.; Denetleme - C.B., S..G.; Kaynaklar - S..G.; Malzemeler - C.B., Ş.G.; Veri Toplama ve/veya İşleme - C.B., Ş.G.; Analiz ve/veya Yorum - G.G.; Literatür Taraması - C.B.; Yazıyı Yazan - C.B., S..G.; Eleştirel İnceleme - C.B.

\section{REFERENCES}

1. Shields TW. General thoracic surgery. 7th ed. Philadelphia, PA; London: Wolters Kluwer Health/Lippincott Williams \& Wilkins. 2009.

2. Lesaffer J, Heremans B, De Leyn P, Raemdonck DV. Video-assisted mediastinoscopic resection of large symptomatic bronchogenic cyst. Interact Cardiovasc Thorac Surg $2011 ; 12: 1071-3$. [CrossRef]

3. Martinod E, Pons F, Azorin J, Mouroux J, Dahan M, FailIon JM, et al. Thoracoscopic excision of mediastinal bronchogenic cysts: results in 20 cases. Ann Thorac Surg 2000; 69:1525-8. [CrossRef]

4. Chang YC, Chang YL, Chen SY, Wang TC, Yang PC, Liu $\mathrm{HM}$, et al. Intrapulmonary broncho-genic cysts: comput- ed tomography, clinical and histopathologic correlations. J Formos Med Assoc 2007; 106:8-15. [CrossRef]

5. Parray FQ, Sherwani AY, Dangroo SA, Bisati RA, Malik NS. Retroperitoneal bronchogenic cyst mimicking hydatid liver: a case report. Case Report Surgery 2012; 2012:312147. [CrossRef]

6. Moz U, Gamba P, Pignatelli U, D'Addazio G, Zorzi F, Fiaccavento $S$, et al. Bronchogenic cysts of the neck: a rare localization and reiew of the literature. Acta Otorhinolaryngol Ital 2009; 29:36-40.

7. Hajiar W, El-Madany Y, Ashour M, Al-Kattan K. Life threatening complications caused by bronchogenic and oesophageal duplication cysts in a child. J Cardiovasc Surg (Torino) 2003; 44:135-7.

8. Tiwari MK, Yadav R, Mathur RM, Shrivastava CP. Mediastinal bronchogenic cyst presenting with dysphagia and back pain. Lung India 2010; 27:86-8. [CrossRef]

9. Marshall G, Cheah C, Lenzo NP. Bronchogenic cyst with multiple complications. Biomed Imag-ing Interv J 2007; 3:e42. [CrossRef]

10. Sundaramoorthi T, Mahadevan R, Nedumaran K, Jayaraman S, Vaidyanathan KR. Intrabrochial rupture of bronchogenic cyst. Ann Thorac Surg 2009; 87:1919-20. [CrossRef]

11. Okur E, Altan K, Kuzu Okur H, Ertuğrul M, Halezaroğlu S, Atasalihi A. Bronkojenik kistlerde cerrahi tedavi. Toraks Dergisi 2002; 3:66-9.

12. Bolton JW, Shahian DM. Asymptomatic bronchogenic cysts: what is the best management? Ann Thorac Surg 1992; 53:1 134-7. [CrossRef] 